\title{
Consumers' consciousness of health-friendly products and services and its association with sociodemographic characteristics and health Status
}

\author{
Young Ho Yun ( $\sigma$ lawyun08@gmail.com ) \\ https://orcid.org/0000-0002-2740-7279 \\ Jin-Ah Sim \\ Seoul National University College of Medicine \\ Yaeji Kim \\ Friedrich-Alexander-Universitat Erlangen-Nurnberg \\ Sujee Lee \\ University of Wisconsin Madison \\ Kyoung-Nam Kim \\ Seoul National University College of Medicine
}

\section{Research article}

Keywords: consciousness for health, health-friendly activities, health-friendly products and services

Posted Date: September 7th, 2019

DOI: https://doi.org/10.21203/rs.2.14027/v1

License: (9) (i) This work is licensed under a Creative Commons Attribution 4.0 International License. Read Full License 


\section{Abstract}

Background: Although health policy resides mainly with the government, industry can play an important role in building a health ecosystem. Methods: From March to May, we administered questionnaires to 1,200 individuals from the general Korean population asking about their perception of health-friendly labels, and if they would purchase such labeled products (foods, pharmaceuticals, etc.) and services (purifying water, preventing air pollution, etc.) at extra cost.

Results: The participants placed a high value on the importance of mental, social, spiritual, and physical health factors in terms of company's products and services with a score of about 8 out of 10 (range, 7.74-8.33). Most respondents (72.4\%) said they were interested in adopting health-friendly labels. When a health-friendly label is introduced (such as one by the Business for Social Responsiveness), $65.1 \%$ of the respondents said they intended to purchase the product or service, while $6.8 \%$ said they did not, and $75.0 \%$ said they were willing to pay extra for the health-friendly product or service. Multivariate logistic regression models showed urban residence, high education level, and good social health to be significantly associated with positive attitudes toward health-friendly labels. People with high income, no religion, or normal weight were more likely to say they intend to purchase products and services with health-friendly labels. They also had a more positive attitude toward paying more for such products and services, as did people with good spiritual health.

Conclusion: This study provides data that illustrate the importance of health-friendly products and services to the general population and companies.

\section{Background}

In 1948, the World Health Organization (WHO) Constitution defined health as "a state of complete physical, social, and mental well-being and not merely the absence of disease or infirmity". In recent years, health has been viewed as having four aspects-body, mind, social, and spiritual. Health is determined somewhat by genetics and medical care, but mostly by behavior and social conditions. Health care policy, however, does not accommodate that observation. [1]. In the U.S., for example, approximately $95 \%$ of the health budget goes to medical care services, while only $5 \%$ is allocated to population-based approaches for health improvement [2].

There is an increasing awareness of the importance of social and environmental factors on health and that health is the responsibility of both the government and the private sector [3]. Although current health policy focuses mainly on the role of the government, companies can play an important role in building a framework of health ecosystems [3]. Just as companies can influence the health of employees and customers, they can address corporate social responsibility (CSR). Usually, however, CSR efforts focus on philanthropy and are undertaken largely to meet legal requirements or avoid penalties [4]. But CSR can have a more strategic role by using the company's core systems to create business and express social value by addressing the issue of population health [5] [3]. According to Porter and Kramer,The concept of shared values can be defined as policies and operating practices that enhance the competitiveness of a company while simultaneously advancing the economic and social conditions of the communities in which it operates." (Porter \& Kramer, 2011)5] [6]. Some companies, such as PepsiCo [7], Qualcomm Incorporated [8], Walmart [9], and General Electric [5], found new business opportunities that could prevent or solve specific health challenges [3]. Overall, a few companies outside the food, beverage, and agriculture industries are trying to improve customers' health and wellness [3]. Many sustainability and corporate responsibility programs are 'less bad' rather than 'good' [4].

According to Business for Social Responsibility, consumers nowadays are interested in what a company cares about their health and wellness, health-friendly product and service [3]. For example, consumers can easily accept to buy innovative functional foods with health effects and increasing interest in health might drive a growth in demand for functional health foods with radical innovations.[10] For other example, a famous examples is the announcement Walmart made at the White House, together with then-First Lady Michelle Obama, that the company would open 300 stores to serve the U.S. Department of Agriculture's designated food desert areas to provide easy access to fresh, affordable, and nutritious food so as to foster healthier communities [9]. There is a significant stream of research covering health labelling and its impact on consumer choice [11][12][13]. For example, frequent users of nutrition labels were less likely to consume unhealthy indicator foods[12].

Some studies of consumer purchase decision models indicate that consumer purchase intentions greatly depend on health and price consciousness and on a health label and are uneven across different market segments and cultures [14] [15] [16] [17]. Although some studies have investigated the perception and purchase of organic products and eco labels, few have investigated the same concept on health [16] [16] [18 [19] [20]. Thus, in this study, we aimed to understand consumer perception of health-friendly labels and their purchasing behavior of health-friendly labelled products and services, and to identify associated factors. 
We propose here the concept of "health-friendly management", which refers to the promotion of various healthful components, or the avoidance of harmful components, whether they affect the physical, mental, social, or spiritual aspects of health.

To eliminate factors that may impair health, it is necessary for health-friendly products and services to meet safety regulations through quality control of raw materials, minimization of harmful elements, or the improvement of mental, social, and spiritual health. Healthfriendly management, thus, deals with health-friendly products and services as a corporate responsibility. From our literature review, we hypothesized that consumer's demographic characteristics such as education and income, and their health status might influence their attitude toward health-friendly products and services (consumer reaction, purchase intention, and willingness to pay more) [16] [17] [19] [20] [21] 22] [23] [24] [25] [26].

\section{Methods}

\section{Participants and procedures}

Data were collected from a broader general Korean population targeted in the survey. Firstly, the survey was conducted with the general population aged 20-70 years and residing across 17 major cities and local districts from March to May 2018. In each major city and local district, all participants were recruited taking the age and sex strata by region into account and applying probability proportion-to-size sampling in accordance with the 2016 Korean census. We used a probability-proportional-to-size technique for sample selection to to select a representative national sample, particularly when the sample groups differ in size. [27]. Among 4000 eligible persons, 1,200 people (30\% response rate) of them responded to the self-reported questionnaire in the presence of the interviewer, who could provide further explanation on the study. This method is widely used trained research assistants administered a semi-structured, self-reported questionnaire. The World Research Co., Ltd., (Seoul, Korea) conducted the survey. All recruiters provided informed consent.

Ethics approval was obtained from the Institutional Review Board of the Seoul National University for the participants' self-reported questionnaire. All participants provided oral informed consent.

\section{Measurement}

The survey items were formulated on the basis of published studies [28][29][30][31]. Accordingly, these 3 items were generated: (1) How would you feel about companies when you see their health-friendly labeled products or services? The participants could respond with one of the following: "They are trustworthy", "They care about consumers' health", "The cost is high", or "No special feeling". (2) Would you prefer the health-friendly labeled products and services to others not so labeled? (5-point Likert scale with 1, not at all; 2, a little; 3 , moderate; 4 , quite a bit; 5 , very much.) (3) Would you be willing to pay more for the health-friendly labeled product or service? If so, how much more compared with the label-free product price?" (1, no more; 2 , less than $5 \% ; 3,5 \%$ 10\%; 4, 11\% 15\%; 5, 16\% 20\%; 6, more than $21 \%)$. To measure the impact of different aspects of health status on health-friendly consciousness, we assessed the respondents' health on the basis of a holistic point of view [32]. The items measuring physical, mental, social, and spiritual health status were applied as follows: "Physical health is the state of having normal physical strength, without diseases and injuries. What do you think about your physical health status?" "Mental health is the state of being mentally stable, being able to overcome stress. What do you think about your mental health status?" "Social health is the state of having good social relationships, carrying out one's work properly. What do you think about your social health status?" "Spiritual health is the state of adding meaning to life through volunteering, religious experiences, and meditation. What do you think about your spiritual health status?" In addition, we measured general health status with the following question: "Considering your physical, mental, social, and spiritual health status, what do you think about your health status in general?" All the items used a 5-point Likert scale with "Excellent", "Very Good", “Good", "Poor", and "Bad".

In addition, the respondents were asked which subscales of each health aspect they considered important for the pursuit of a company's health-friendly products or services. They were given the subscales of four health aspects ( 5 subscales each), and asked to rate the importance of each on a scale of 0 to 10. (Table 2). The respondents' sociodemographic and health information we collected included age, sex, residence, religion, marital status, education, monthly income, job status, body mass index (BMI), comorbidities, and smoking experience.

\section{Statistical analysis}


Using descriptive statistics for the sociodemographic variables, we calculated the mean \pm SD scores of the importance of the impact of the 4 health factors (physical, mental, social, and spiritual) for corporations that made health-friendly products or services. To test the reliability of the the variables of health-friendly activities, we estimated Cronbach's a, which is a measure of internal consistency of patient responses. Then we performed univariate analyses to measure sociodemographic correlates for each aspect of health consciousness (consumer reaction, purchase intention, and willingness to pay more). The sociodemographic factors that were determined to be significant in univariate analysis were used to examine the association between the sociodemographic variables those of more positive health consciousness. The sociodemographic variables were included in univariate analyses based on the literature reviews [16] [17] [19] [20] [21] 22] [23] [24] [25] [26] and screening potentially element associated with the health consciousness.

We also compared the proportions of health consciousness using a chi-squared test to evaluate the impact of five categories of health status (physical, mental, social, spiritual, and general health). In all analyses, we determined two-sided $P$-values and considered a $P$-value less than 0.05 to be significant. In final model, we used the factors that were determined to be significant in univariate analyses to examine the association between the sociodemographic variables, health status, and those of more positive health consciousness. We conducted three multiple regression analyses using the hierarchical/stepwise method to identify independent factors with statistical significance. We conducted a univariate analysis with the aim of screening potentially existing elements to learn from existing data and draw implications. Therefore, univariate analysis was not a meaningful thing in itself, but a step to build a model for the final multivariate analysis. As a result, the final multivariate analysis results were meaningful and the researchers evaluated it. We also performed a sensitivity analysis by further calibrating the age-square along with the age variable in the multivariate analysis, confirming that most results were maintained. In the case of Income variables, obtained and analyzed in a categorical manner, without logarithmic conversion of income variables, there are no problems caused by extreme values. We considered $P<0.05$ as statistically significant and reported results as the odds ratio (OR) with a $95 \% \mathrm{Cl}$. We used SAS, version 9.3 software (SAS Institute, Cary, NC, USA) for all analyses.

\section{Results}

\section{Sociodemographic characteristics of the participants}

Table 1 shows sociodemographic characteristics of the 1,200 survey participants. The mean age \pm SD of the study participants was 46.97 \pm 14.18 years.

\section{Factors that are important for the health-friendly activities of companies to affect consumers' four aspect of health}

The respondents evaluated the mental, social, spiritual, and physical health factors incorporated into products or services highly. Table 2 shows the scores for the various aspects of the four factors. All values on the variables of the health-friendly activities showed a high reliability with good internal consistency.

\section{Acceptance of health-friendly label and intent to purchase its products or services}

Most respondents (72.4\%) said they were interested in adopting the health-friendly label, evaluating the companies' health-friendly activities in various areas. In detail, $36.5 \%$ of the respondents believed that the companies thought about consumers' health, and $35.9 \%$ felt that they could believe the label claims and purchase the products or services. When a health-friendly label is introduced by a company, $65.1 \%$ of the respondents said they intended to purchase the product/service, $6.8 \%$ said they did not, and $75.1 \%$ said that they were willing to pay more for it (Figure 1).

\section{Association of demographic characteristics and health status with health-friendly label, intent to purchase its product/services, and willing to pay extra price, univariate logistic analysis}


Tables 3 and 4 show the association of demographic characteristics and health status with consciousness of health-friendly products and services, intent to purchase the product or services, and willingness to pay a higher price for them. As for the domain of consumer reaction, 5 demographic variables (young age, place of residence, religion, education, higher $\mathrm{BMI}$ ) and 2 types of health status (good mental health and social health) were statistically significant.

Significantly related to the domain of purchase intention were social health status as well as the demographic factors of age, religion, education, monthly income, and BMI. In addition, significantly associated with additional payment intention were the demographic factors of younger age, education, monthly income, and BMl, as were physical, mental, spiritual, and general health status.

\section{Multivariate logistic regression models for factors associated with health-friendly labels, intent to purchase its product or services, and willingness to pay a higher price}

Multivariate logistic regression models show that the consumers residing in urban areas, highly educated, and having good social health status showed a more positive reaction to health-friendly labels. Respondents with a higher income level, normal BMI, and no religion were more likely to express an intention to purchase products and services with a health-friendly label, whereas no health status was significantly associated with that intent. In addition, factors such as higher education, higher income level, normal BMI, and good spiritual health were associated with having a more positive attitude toward paying extra for products and services with health-friendly labels (Table 5). Significant correlations in some univariate analyzes such as age, physical, mental and general health status have lost significance in multivariate analysis, which may be due to correlation and confounding between variables.

\section{Discussion}

This study provides a better understanding of the importance to consumers of products or services that provide physical, mental, social, and spiritual health. In addition, this study suggests the need for a health-friendly certification mark or label recognized by the general population. Our findings suggest that consumers are demanding health-friendly products and services and are willing to pay the extra cost involved.

Companies' marketing activities can play a significant role in raising the public awareness of health [3]. Business for Social Responsibility, a global nonprofit organization working to build "a just and sustainable world," confirmed that member companies support the idea that they can strengthen the health and wellness of their customers and the public. About $90 \%$ of the companies agree that they can help strengthen the health of their consumers, while about $75 \%$ agree that they can help strengthen public health [3]. Shared value models may represent the next evolution of capitalism [6]. In the U.S., for example, Kaiser Permanente partnered with Home Box Office, the National Institutes of Health, the Centers for Disease Control and Prevention, the Institute of Medicine, and the Michael \& Susan Dell Foundation and launched public health campaigns addressing the obesity epidemic [33]. Moreover, companies can partner with local governments to encourage healthy lifestyles or habits. For the National Salt Reduction Initiative, for instance, more than 100 state and local health authorities and national health organizations partnered with many companies to reduce the amount of sodium in packaged and restaurant foods (https://www1.nyc.gov/site/doh/health/health-topics/national-salt-reduction-initiative.page\#national-salt-reductioninitiative).

Although our findings showed that consumers with a high-education level or who lived in an urban area had a more positive attitude towards health-friendly labels, that non-religious, high-income, or normal-weight consumers had intentions to purchase products and services with a health-friendly label, and that people with high-education level, high-income, or normal-weight had a positive attitude toward paying more for products and services with a health-friendly label, other studies had inconsistent findings between demographic characteristics and purchase intention toward green products [19] [21]. Our finding that consumers with good health status would be cautious about products and services with a health-friendly label and expressed willingness to pay more for them are consistent with the finding that health consciousness is an important factor that influences the purchase of organic foods [16] [17] [22] [23]. Our results seem to be consistent with the finding that eco-label and the value of green products had the strongest positive influence on green product purchase intention and were associated with the willingness to pay more for environmentally certified products, the eco-label, or the energy-label [20] [21] [24] [25] [26].

These studies imply that most consumers perceive the health-friendly label as importantwhen purchasing products or services. Emphasizing the health-friendly label of products or services accredited by reputable organizations would help to build reliability and

Page 5/13 
awareness among consumers, but the products and services would be more expensive than conventional products and services [20] [21], and that could negatively influence purchasing. Thus, managers are challenged with the need to produce high quality products and services at affordable prices [20].

To integrate health-friendliness into its value chain and culture, companies can start by meeting social needs through products or services that serve the unserved or underserved [5] [6] [15]. It can motivate employees to strengthen the health of their customers through daily actions and business decisions. Companies can use key performance indicators and report them in their sustainability report in a comprehensive and transparent way [3].

Many companies, however, would struggle when trying to integrate a health and wellness agenda into their value chain. Many CEOs cite a lack of recognition from the financial market as a barrier to achieving their sustainability goals [34]. But it is necessary to focus not only on preventive and holistic health, but also on return on investment. Stakeholders from managers, employees, investors, consumers, community organizations, and government should form a consensus that companies should try to contribute to consumer and public health through a mission that goes beyond mere profit. "The purpose of business is to serve society, through the provision of safe, high quality products and services that enhance our well-being, without eroding our ecological and community life-support systems ultimately." [4]. The government also should consider ways to assist these companies through tax breaks or their health insurance premium cuts [3].

Although the scope of this study is so broad that cover all products and services and health also very broadly defined across 4 different domains, consumers think that corporate products or services have very important impact on not only their physical health, but also mental, social and spiritual health and there was no difference in importance among the 4 different domains of health. It might be crucial to develop measure to evaluate the health-friendly activities of corporates across 4 different domains of health in an objective and reasonable manner and to apply "health-friendly label" to the products and services of corporates.

This study had some limitations. The first is that it was conducted in Korea and the findings might not apply to other populations. Second, since this is a cross-sectional study, we could not attribute causality between attitudes toward health-friendly labels and intent to purchase health-friendly products or services. Further studies are needed to examine the associations. Third, almost all respondents would automatically agree with the questions in our survey and we did not address the gap between attitudes and behavior. Four, our hypothesis that consumer's demographic characteristics might influence their attitude toward health-friendly products and services have the limitation of study design. Especially educated people tend to give socially desired responses in surveys, i.e. to say that they would prefer health-friendly products and be willing to pay more for them. Therefore, Discrete Choice Modeling (Choice-Based Conjoint analysis) would be more suitable method to find out the preferences of features and products to simulate market and create optimal products. Finally, it is also a limitation that the respondents' use of health-friendly products or knowledge of such products was not asked at all in the survey although these factors might explain the attitudes towards the products. Further studies are needed to examine the associations of the consumers' use of health-friendly products or knowledge of the products with attitude toward health-friendly products and services.

\section{Declarations}

Funding: This work was supported by a Seoul National University Research Grant in 2016 (800-20170241).

Potential Financial Conflicts of Interest: None disclosed

Availability of data and materilas: None

\section{References}

1.McGinnis, J. M.; Williams-Russo, P.; Knickman, J. R., The case for more active policy attention to health promotion. Health Aff (Millwood) 2002, 21, (2), 78-93.

2.Centers for Disease, C., Estimated national spending on prevention-United States, 1988. MMWR Morb Mortal Wkly Rep 1992, 41, (29), 529-31.

3.BSR, A New CSR Frontier: Business and Population Health. In 2013.

4.Visser, W., The Age of Responsibility: CSR 2.0 and the New DNA of Business Journal of Business Systems, Governance and Ethics 2010, $5,(3), 7$. 
5.Kottke, T. E.; Pronk, N.; Zinkel, A. R.; Isham, G. J., Philanthropy and Beyond: Creating Shared Value to Promote Well-Being for Individuals in Their Communities. Perm J 2017, 21.

6.Moore, C. Corporate Social Responsibility and Creating Shared Value: What's the Difference?; 2014.

7.Pepsico PEPSICO GLOBAL SUSTAINABLE AGRICULTURE POLICY.

8.Qualcomm, Qualcomm Life and WebMD Collaborate to Bring Integrated Digital Health Resources and Tools to Consumers. In Qualcomm Life's 2net Ecosystem attracts new technology partners with release of 2net Hub API and SDK and launch of 2net Ecosystem Technology Certification Program at the 2013 HIMSS Conference in New Orleans, LA, NEW ORLEANS AND SAN DIEGO, 2013.

9.Walmart, Walmart to Open up to 300 Stores Serving USDA Food Deserts by 2016; More than 40,000 Associates Will Work in These Stores. In About 500 new and existing locations will provide access to more than 700 USDA food deserts serving approximately 1.3 million people Washington, D.C.

10.Puhakka, R.; Valve, R.; Sinkkonen, A., Older consumers' perceptions of functional foods and non-edible health-enhancing innovations. International Journal of Consumer Studies 2018, 42, (1), 111-119.

1. Rimpeekool, W.; Kirk, W.; Yiengprugsawan, V.; Banwell, C.; Seubsman, S.; Sleigh, A., Nutrition label experience and consumption of transitional foods among a nationwide cohort of 42,750 Thai adults, 2017, British Food Journal, 119, (2), 425-439.

2. Montandon, A. C.; Colli, C., Effective nutrition labels for fast food consumers, British Food Journal, 2016, 118, (10), $2534-2549$.

3. Hassan, L. M.; Shiu, E., A systematic review of the efficacy of alcohol warning labels: Insights from qualitative and quantitative research in the new millennium, Journal of Social Marketing, 2018, 8, (3), 333-352.

4. Peattie, K.; Ratnayaka, M., Responding to the green movement. Industrial Marketing Management 1992, 21, (2), 103-110.

15.Ottman, J., Sometimes Consumers Will Pay More to Go Green. Journal of International Consumer Marketing 1992, 16, (12), 120.

16.Kabir, A.; Jahan, K., Factors of Consumers Perceptions \& Purchase Intentions towards Green Products. 2014; Vol. 35, p 239-256.

17.OZ, Y.; OZBUK, M. Y. In Consumer Clusters Based on Health and Price Consciousness, Proceedings of the International Academic Research Conference on Marketing \& Tourism Paris, France, 07.01.2016, 2016; Paris, France, 2016.

18.Jindabok, T. In The Relationship of Thai Consumers' Health Consciousness and Perceived Value, Proceedings of the Second Middle East Conference on Global Business, Economics, Finance and Banking, Dubai, May 2015, 2015; Dubai, 2015 ; pp 22-24.

19.Sukanya Chowtanapanich, S. C. In Identifying Factors Influencing Purchase Intentions of Non-Blackmores Users, International Conference on Trends in Economics, Humanities and Management (ICTEHM'14), Pattaya, Thailand, 08.13.2014, 2014; Pattaya, Thailand, 2014.

20.Kong, W.; Harun, A.; Sulong, R.; Lily, J., The Influence of Consumers Perception of Green Products on Green Purchase Intention. 2014; Vol. 4, p 924-939.

21.Singh, S.; Singh, D.; Thakur, K. S., Consumer's Attitude and Purchase Intention Towards Green Products in the FMCG Sector. Pacific Business Review International 2014, 7, (6), 27-46.

22.Akhondan, H.; Johnson-Carroll, K.; Rabolt, N., Health Consciousness and Organic Food Consumption. Journal of Family \& Consumer Sciences 2015, 107, (3), 27-32.

23.Tan Poh Leong; Paim, L., Mediating Effects of Intention On The Factors Affecting Organic Food Products Consumption Among Chinese Generation Y In Malaysia. International Journal of Business Research and Management (IJBRM) 2015, 6, (1), 1-19.

24.Volsky, R. P., Ozanne, L. K., Fontenot, R. J., A conceptual model of US consumer willingness-to-pay for environmentally certified wood products. Journal of Consumer Marketing 1999, 16, (2), 122-140.

25.D'Souza, C., Bridging the communication gap: dolphin-safe "ecolabels". Corporate Communications: An International Journal 2000, 5, (4), 185-190. 
26.Sammer, K.; Wüstenhagen, R., The influence of eco-labelling on consumer behaviour-results of a discrete choice analysis for washing machines. Business Strategy and the Environment 2006, 15, (3), 185-199.

27.Levy, P. S., Sampling. Wiley: New York, 1965.

28.Lea, E.; Worsley, T., Australians' organic food beliefs, demographics and values. British food journal 2005, 107, (11), 855-869.

29.Lichtenstein, D. R.; Ridgway, N. M.; Netemeyer, R. G., Price perceptions and consumer shopping behavior: a field study. Journal of marketing research 1993, 234-245.

30.Michaelidou, N.; Hassan, L. M., The role of health consciousness, food safety concern and ethical identity on attitudes and intentions towards organic food. International Journal of Consumer Studies 2008, 32, (2), 163-170.

31.Schifferstein, H. N.; Ophuis, P. A. O., Health-related determinants of organic food consumption in the Neterlands. Food quality and Preference 1998, 9, (3), 119-33.

32.Yun, Y. H.; Sim, J. A.; Park, E.-G.; Park, J. D.; Noh, D.-Y., Employee health behaviors, self-reported health status, and association with absenteeism: Comparison with the general population. Journal of Occupational and Environmental Medicine 2016, 58, (9), 932-939.

33.Permanente, K., Kaiser Permanente Joins HBO and Leading Health Organizations to Present The Weight of the Nation. In Groundbreaking documentary series launches public health campaign to address America's obesity epidemic, Oakland, CA., 2012.

34.Neuberger, P. L. T. C. R. H. L. A New Era of Sustainability UN Global Compact-Accenture CEO Study 2010; Accenture Sustainability Service; the UN Globacl Compact 2010.

\section{Tables}

Table 1. Sociodemographic Characteristics of Participants. 


\begin{tabular}{|c|c|c|c|}
\hline Variable & & $\mathbf{N}=1,200$ & $\%$ \\
\hline \multirow[t]{2}{*}{ Sex } & Male & 592 & 49.3 \\
\hline & Female & 608 & 50.7 \\
\hline \multirow[t]{5}{*}{ Age, years } & $20-29$ & 194 & 16.2 \\
\hline & $30-39$ & 212 & 17.7 \\
\hline & $40-49$ & 249 & 20.8 \\
\hline & $50-59$ & 239 & 19.9 \\
\hline & $\geq 60$ & 306 & 25.5 \\
\hline \multirow[t]{5}{*}{ Religion } & Protestantism & 213 & 17.8 \\
\hline & Buddhism & 178 & 14.8 \\
\hline & Catholic & 98 & 8.2 \\
\hline & No religion & 709 & 59.1 \\
\hline & Other & 2 & 0.2 \\
\hline \multirow[t]{4}{*}{ Marriage } & Married & 884 & 73.7 \\
\hline & Widowed & 34 & 2.8 \\
\hline & Divorced/separated & 17 & 1.4 \\
\hline & Single & 265 & 22.1 \\
\hline \multirow[t]{5}{*}{ Education } & Elementary school graduate & 27 & 2.3 \\
\hline & Middle school graduate & 92 & 7.7 \\
\hline & High school graduate & 537 & 44.8 \\
\hline & College degree or higher & 539 & 44.9 \\
\hline & Non-schooled & 5 & 0.4 \\
\hline \multirow[t]{3}{*}{ Residence } & Metropolitan & 543 & 45.3 \\
\hline & Urban & 592 & 49.3 \\
\hline & Rural & 65 & 5.4 \\
\hline \multirow{5}{*}{$\begin{array}{l}\text { Monthly income, KRW } \\
(1000 \mathrm{KRW}=0.9 \mathrm{USD})\end{array}$} & $\leq 1,000,000$ & 30 & 2.5 \\
\hline & $1,000,000 \sim 1,999,999$ & 89 & 7.4 \\
\hline & $2,000,000 \sim 2,999,999$ & 188 & 15.6 \\
\hline & $3,000,000 \sim 3,999,999$ & 344 & 28.7 \\
\hline & $\geq 4999,999$ & 543 & 45.3 \\
\hline \multirow[t]{4}{*}{ Job status } & Own Business & 291 & 24.3 \\
\hline & Employed & 549 & 45.8 \\
\hline & Unemployed & 342 & 28.5 \\
\hline & Retired & 18 & 1.5 \\
\hline \multirow[t]{4}{*}{$\mathrm{BMI}$} & $<18.5$ & 41 & 3.4 \\
\hline & $18.5-23.49$ & 686 & 57.4 \\
\hline & $23.5-24.99$ & 245 & 20.5 \\
\hline & $\geq 25$ & 224 & 18.7 \\
\hline
\end{tabular}

Table 2. Mean, standard deviation (SD) and cronbach's $\alpha$ of the company's health-friendly activities that have a significant impact on consumers' health. 


\begin{tabular}{|c|c|c|c|}
\hline Item & Mean & SD & Cronbach's $\alpha$ \\
\hline Company's health-friendly activities that have an important impact on consumers' physical healt| & & & 0.889 \\
\hline Reflecting physical health status during product / service development / improvement & 7.71 & 1.33 & \\
\hline Reflecting the enhancement of physical health activities when developing / improving products / services & 7.76 & 1.35 & \\
\hline Quality control for raw materials & 8.02 & 1.43 & \\
\hline Minimization of harmful elements of production / service process & 8.03 & 1.39 & \\
\hline Active compensation for health related accidents & 7.95 & 1.37 & \\
\hline Company's health-friendly activities that have an important impact on consumers' mental health & & & 0.904 \\
\hline Reflecting mental health status during product / service development / improvement & 7.78 & 1.29 & \\
\hline Reflecting the promotion of mental health activities when developing / improving products / services & 7.80 & 1.33 & \\
\hline Customer Friendly service & 7.94 & 1.34 & \\
\hline Actively coping with customer complaints & 8.02 & 1.27 & \\
\hline Building confidence in corporation made products / services & 8.06 & 1.25 & \\
\hline Company's health-friendly activities that have an important impact on consumers' social health & & & 0.908 \\
\hline Reflecting social health status during product / service development / improvement & 7.74 & 1.20 & \\
\hline Reflecting on social health activities promotion when developing / improving products / services & 7.75 & 1.34 & \\
\hline Building constant relationship with customers & 7.83 & 1.39 & \\
\hline Respecting customers without discrimination & 7.95 & 1.31 & \\
\hline Contribution to improvement of family / relationship with others & 7.83 & 1.21 & \\
\hline Company's health-friendly activities that have an important impact on consumers' spiritual health & & & 0.913 \\
\hline Reflecting spiritual health status during product / service development / improvement & 7.61 & 1.36 & \\
\hline Reflecting on spiritual health activities promotion when developing / improving products / services & 7.66 & 1.37 & \\
\hline Whether products / services respect person as a human being & 7.83 & 1.39 & \\
\hline Whether products /services make person feel worthy and valuable & 7.84 & 1.34 & \\
\hline Whether products / services help improve life satisfaction & 7.80 & 1.29 & \\
\hline
\end{tabular}

Abbreviation: SD, Standard Deviation

Table 3. Univariate analysis of correlation of participants' consciousness of company's health-friendly activities with demographic and health behaviors $\left({ }^{*} p<0.05\right)$. 


\begin{tabular}{|c|c|c|c|c|c|c|c|c|c|c|}
\hline \multirow[t]{2}{*}{ Predictors } & \multirow[t]{2}{*}{$\mathrm{n}(\%)$} & \multicolumn{3}{|c|}{ Consumer Reaction } & \multicolumn{3}{|c|}{ Purchase Intention } & \multicolumn{3}{|c|}{ Additional Payment Intention } \\
\hline & & $\begin{array}{l}\text { Negative } \\
\text { Response }\end{array}$ & $\begin{array}{l}\text { Positive } \\
\text { Response }\end{array}$ & $\begin{array}{l}p- \\
\text { value }\end{array}$ & $\begin{array}{l}\text { Negative } \\
\text { Response }\end{array}$ & $\begin{array}{l}\text { Positive } \\
\text { Response }\end{array}$ & $p$-value & $\begin{array}{l}\text { Negative } \\
\text { Response }\end{array}$ & $\begin{array}{l}\text { Positive } \\
\text { Response }\end{array}$ & $p$-value \\
\hline \multicolumn{11}{|l|}{ Age, years } \\
\hline $20-59$ & $894(74.5)$ & 231(25.8) & $663(74.2)$ & $0.006 *$ & 292(32.7) & 602(67.3) & $0.004^{*}$ & 198(22.1) & 696(77.9) & $<0.001 *$ \\
\hline$\geq 60$ & $306(25.5)$ & 104(34.0) & $202(66.0)$ & & $128(41.8)$ & $176(58.2)$ & & 101(33.0) & $205(67.0)$ & \\
\hline \multicolumn{11}{|l|}{ Sex } \\
\hline Male & $592(49.3)$ & 159(26.9) & $433(73.1)$ & 0.42 & $212(35.8)$ & $380(64.2)$ & 0.561 & $146(24.7)$ & $446(75.3)$ & 0.841 \\
\hline Female & $608(50.7)$ & $176(28.9)$ & $432(71.1)$ & & $208(34.2)$ & $400(65.8)$ & & $153(25.2)$ & $455(74.8)$ & \\
\hline \multicolumn{11}{|l|}{ Residence } \\
\hline Rural/suburban & $657(54.8)$ & 209(31.8) & $448(68.2)$ & $0.001^{*}$ & 228(34.7) & 429(65.3) & 0.813 & 177(26.9) & 480(73.1) & 0.075 \\
\hline Urban & $543(45.3)$ & $126(23.2)$ & 417(76.8) & & 192(35.4) & 351(64.6) & & $122(22.5)$ & $421(77.5)$ & \\
\hline \multicolumn{11}{|l|}{ Religion } \\
\hline None & 711(59.3) & 182(25.6) & $529(74.4)$ & $0.031^{*}$ & 218(30.7) & 493(69.3) & $<0.001^{*}$ & 175(24.6) & $536(75.4)$ & 0.769 \\
\hline Yes & $489(40.8)$ & 153(31.35) & $336(68.7)$ & & 202(41.3) & 287(58.7) & & $124(25.4)$ & $365(74.6)$ & \\
\hline \multicolumn{11}{|l|}{ Marriage } \\
\hline Not married & $316(26.3)$ & $87(27.5)$ & $229(72.5)$ & 0.859 & 117(37.0) & 199(63.0) & 0.379 & 78(24.7) & 239(75.3) & 0.911 \\
\hline Married & $884(73.7)$ & $248(28.1)$ & 636(71.9) & & $303(34.3)$ & $581(65.7)$ & & $221(25.0)$ & 663(75.0) & \\
\hline \multicolumn{11}{|l|}{ Education } \\
\hline $\begin{array}{l}\leq \text { High school } \\
\text { graduate }\end{array}$ & $661(55.1)$ & 204(30.9) & $457(69.1)$ & $0.012 *$ & 259(39.2) & 402(60.8) & $0.001 *$ & 193(29.2) & $468(70.8)$ & $<0.001^{*}$ \\
\hline $\begin{array}{l}\text { College } \\
\text { graduate }\end{array}$ & $539(44.9)$ & $131(24.3)$ & 408(75.7) & & 161(29.9) & $378(70.1)$ & & 106(19.7) & $433(80.3)$ & \\
\hline \multicolumn{11}{|c|}{ Monthly Income, KRW (1000 KRW = 0.9 USD) } \\
\hline$<3,000$ & $307(25.6)$ & 97(31.6) & 210(68.4) & 0.096 & $136(44.3)$ & 171(55.7) & $<0.001$ & 101(32.9) & 206(67.1) & $<0.001$ \\
\hline$\geq 3,000$ & $893(74.4)$ & 238(26.7) & 655(73.3) & & 284(31.8) & $609(68.2)$ & & 198(22.2) & 695(77.8) & \\
\hline \multicolumn{11}{|l|}{ Employed } \\
\hline Yes & $840(70.0)$ & $235(28.0)$ & $605(72.0)$ & 0.944 & 292(34.8) & $548(65.2)$ & 0.792 & 205(24.4) & $635(75.6)$ & 0.531 \\
\hline No & $360(30.0)$ & $100(27.8)$ & $260(72.2)$ & & 128(35.6) & 232(64.4) & & $94(26.1)$ & 266(73.9) & \\
\hline \multicolumn{11}{|l|}{ Overweight (BMI) } \\
\hline$<23.5$ & $727(60.6)$ & 188(25.9) & $539(74.1)$ & 0.049 & $230(31.6)$ & 497(68.4) & 0.002 & 154(21.2) & 573(78.8) & $<0.001$ \\
\hline$\geq 23.5$ & 473(39.4) & 147(31.1) & $326(68.9)$ & & $190(40.2)$ & $283(59.8)$ & & 145(30.7) & $328(69.3)$ & \\
\hline
\end{tabular}

Table 4. Univariate analysis of correlation of participants' consciousness of health-friendly product/services with health status ( $\left.{ }^{\star} p<0.05\right)$.

\begin{tabular}{|c|c|c|c|c|c|c|c|c|c|c|}
\hline \multirow[t]{2}{*}{ Predictors } & \multirow[t]{2}{*}{$\mathrm{N}(\%)$} & \multicolumn{3}{|c|}{ Consumer Reaction } & \multicolumn{3}{|c|}{ Purchase Intention } & \multicolumn{3}{|c|}{ Additional Payment Intention } \\
\hline & & $\begin{array}{l}\text { Negative } \\
\text { Response }\end{array}$ & $\begin{array}{l}\text { Positive } \\
\text { Response }\end{array}$ & $\begin{array}{l}p- \\
\text { value }\end{array}$ & $\begin{array}{l}\text { Negative } \\
\text { Response }\end{array}$ & $\begin{array}{l}\text { Positive } \\
\text { Response }\end{array}$ & $\begin{array}{l}\mathrm{p}- \\
\text { value }\end{array}$ & $\begin{array}{l}\text { Negative } \\
\text { Response }\end{array}$ & $\begin{array}{l}\text { Positive } \\
\text { Response }\end{array}$ & p-value \\
\hline \multicolumn{11}{|c|}{$\begin{array}{l}\text { Physical } \\
\text { health status }\end{array}$} \\
\hline Poor & 221(18.4) & $66(29.9)$ & 155(70.1) & 0.475 & $78(35.3)$ & $143(64.7)$ & 0.919 & $67(30.3)$ & $154(69.7)$ & $0.04 * *$ \\
\hline$\geq$ good & $979(81.6)$ & $269(27.5)$ & $710(72.5)$ & & $342(34.9)$ & $637(65.1)$ & & 232(23.7) & 747(76.3) & \\
\hline \multicolumn{11}{|c|}{$\begin{array}{l}\text { Mental Health } \\
\text { Status }\end{array}$} \\
\hline Poor & 121(10.1) & 44(36.4) & $77(63.6)$ & $0.029 *$ & $46(38.0)$ & $75(62.0)$ & 0.463 & $40(33.1)$ & $81(66.9)$ & $0.029 * *$ \\
\hline$\geq$ good & 1079(89.9) & 291(27.0) & 788(73.0) & & 374(34.7) & 705(65.3) & & $259(24.0)$ & $820(76.0)$ & \\
\hline \multicolumn{11}{|c|}{$\begin{array}{l}\text { Social Health } \\
\text { Status }\end{array}$} \\
\hline Poor & $83(6.9)$ & $35(42.2)$ & $48(57.8)$ & $0.003^{*}$ & $40(48.2)$ & $43(51.8)$ & $0.009 *$ & $27(32.5)$ & $56(67.5)$ & $0.096 *$ \\
\hline$\geq$ good & $1117(93.1)$ & $300(26.9)$ & 817(73.1) & & $380(34.0)$ & $737(66.0)$ & & $272(24.4)$ & $845(76.5)$ & \\
\hline \multicolumn{11}{|c|}{$\begin{array}{l}\text { Spiritual } \\
\text { Health Status }\end{array}$} \\
\hline Poor & 112(9.3) & $38(33.9)$ & $74(66.1)$ & 0.136 & $46(41.1)$ & $66(58.9)$ & 0.157 & $45(40.2)$ & $67(59.8)$ & $<0.001^{* *}$ \\
\hline$\geq$ good & 1088(90.7) & 297(27.3) & 791(72.7) & & 374(34.4) & 714(65.6) & & 254(23.3) & 834(76.7) & \\
\hline \multicolumn{11}{|c|}{$\begin{array}{l}\text { General } \\
\text { Health Status }\end{array}$} \\
\hline Poor & $90(7.5)$ & $32(35.6)$ & $58(64.4)$ & 0.093 & $34(37.8)$ & $56(62.2)$ & 0.566 & $36(40.0)$ & $54(60.0)$ & $0.001^{*}$ \\
\hline$\geq$ good & 1110(92.5) & $303(27.3)$ & $807(72.7)$ & & $386(34.8)$ & $724(65.2)$ & & 263(23.7) & $847(76.3)$ & \\
\hline
\end{tabular}


Table 5. Multivariate analyses* of participants' consciousness of health-friendly product/services with sociodemographic variables and health status.

\begin{tabular}{|c|c|c|c|c|}
\hline Predictor & $\mathrm{n}(\%)$ & $\begin{array}{l}\text { Positive Consumer Reaction } \\
\mathrm{aOR}^{\star}(95 \% \mathrm{Cl})\end{array}$ & $\begin{array}{l}\text { Positive Purchase Intention } \\
\mathrm{aOR}^{\star}(95 \% \mathrm{Cl})\end{array}$ & $\begin{array}{l}\text { Positive Additional Payment Intention } \\
\mathrm{aOR}^{\star}(95 \% \mathrm{Cl})\end{array}$ \\
\hline \multicolumn{5}{|l|}{ Age } \\
\hline$\geq 60$ & $894(74.5)$ & & & \\
\hline $20-59$ & $306(25.5)$ & NS & NS & NS \\
\hline \multicolumn{5}{|l|}{ Residence } \\
\hline Rural/suburban & $657(54.8)$ & 1 & & \\
\hline Urban & $543(45.3)$ & $1.54(1.19-2.00)$ & - & - \\
\hline \multicolumn{5}{|l|}{ Religion } \\
\hline None & $711(59.3)$ & & 1 & \\
\hline Yes & $489(40.8)$ & NS & $0.66(0.51-0.84)$ & - \\
\hline \multicolumn{5}{|l|}{ Education } \\
\hline$\leq$ High school graduate & $661(55.1)$ & 1 & & 1 \\
\hline College graduate & $539(44.9)$ & $1.30(1.00-1.69)$ & NS & $1.41(1.06-1.87)$ \\
\hline \multicolumn{5}{|c|}{ Monthly Income, KRW (1000 KRW = 0.9 USD) } \\
\hline$<3,000$ & $345(28.7)$ & & 1 & 1 \\
\hline$\geq 3,000$ & $855(71.3)$ & - & $1.46(1.11-1.93)$ & $1.42(1.05-1.92)$ \\
\hline \multicolumn{5}{|l|}{ BMl } \\
\hline$\geq 23.5$ & $966(76.6)$ & & 1 & 1 \\
\hline$<23.5$ & $281(23.4)$ & NS & $1.34(1.04-1.72)$ & $1.42(1.08-1.86)$ \\
\hline \multicolumn{5}{|l|}{ Physical health status } \\
\hline Poor & $221(18.4)$ & & & \\
\hline$\geq$ good & $979(81.6)$ & - & - & NS \\
\hline \multicolumn{5}{|l|}{ Mental health status } \\
\hline Poor & $121(10.1)$ & & & \\
\hline$\geq$ good & 1079(89.9) & NS & - & NS \\
\hline \multicolumn{5}{|l|}{ Social Health Status } \\
\hline Poor & $83(6.9)$ & 1 & & \\
\hline$\geq$ good & 1117(93.1) & $1.79(1.13-2.85)$ & NS & - \\
\hline \multicolumn{5}{|l|}{ Spiritual health status } \\
\hline Poor & $112(9.3)$ & & & 1 \\
\hline$\geq$ good & 1088(90.7) & - & - & $1.90(1.26-2.86)$ \\
\hline \multicolumn{5}{|l|}{ General health status } \\
\hline Poor & $90(7.5)$ & & & \\
\hline$\geq$ good & $1110(92.5)$ & - & - & NS \\
\hline
\end{tabular}

Abbreviations: aOR, adjusted odds ratio; Ref, reference; NS, Non-significant; * Multiple logistic regression analysis including variables identified as independent predictors that showed statistical significance in univariate analysis of correlates of needs for tailored health management program; ${ }^{a}$ The backward-selected multiple logistic regression model identified with sl entry $=0.05$ and sl stay $=0.05$; ${ }^{b}$ Variables that were significantly correlated with a health behavior in the univariate cross-tabulations but not significant in the multivariate analysis are presented as NS; variables not significant in univariate analysis are not included in the model and are presented as ' - .

\section{Figures}




\section{0 \\ (A)}

80.0

60.0

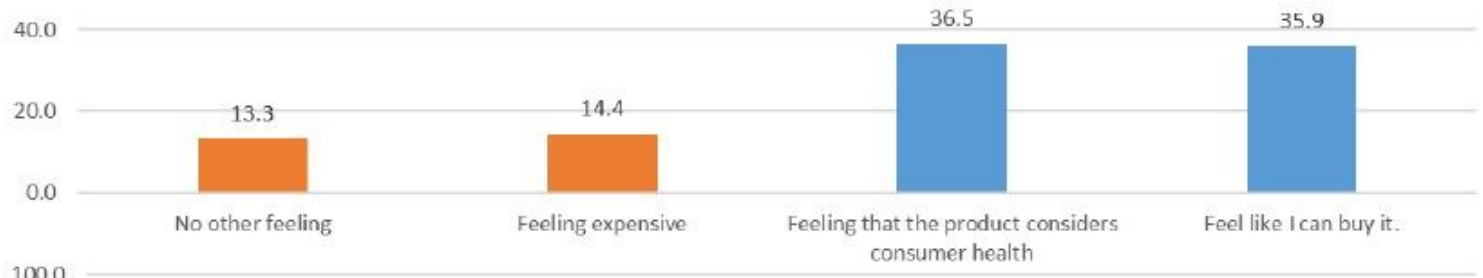

(B)

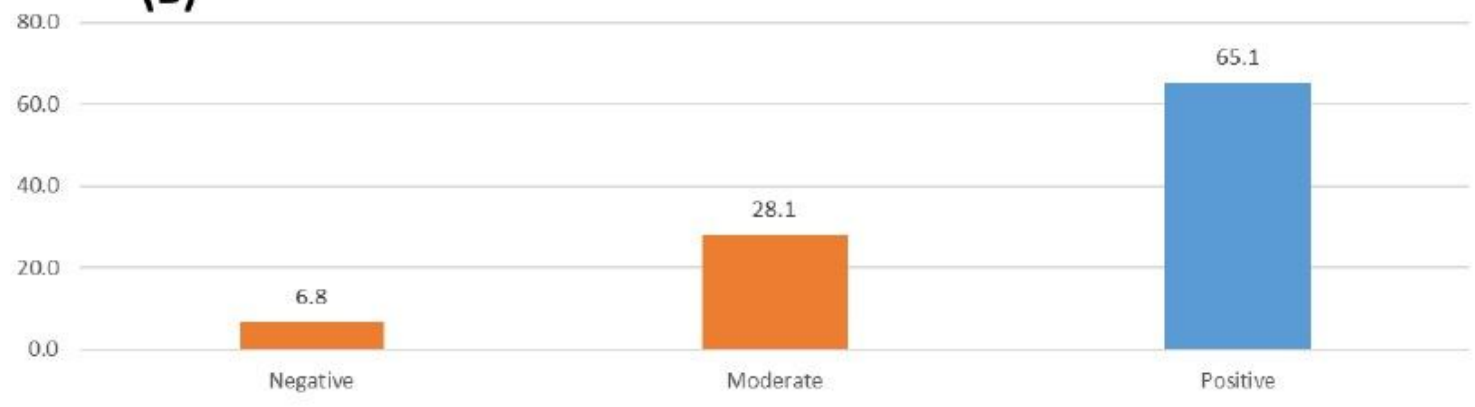

\section{(C) \\ (C)}

80.0

60.0

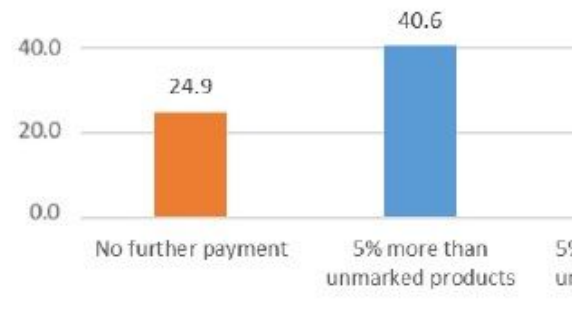

40.6

\section{Figure 1}

Proportions about participants' idea about Friendly index marked products, (A) consumer reaction about health friendly corporation, (B) purchase intention for health friendly index marked products, (C) additional payment intention for health friendly index marked products. 